\title{
Introduction
}

Pia Katila, Carol J. Pierce Colfer, Wil de Jong, Glenn Galloway, Pablo Pacheco and Georg Winkel

\section{The Aim of This Book}

In 2015, 193 countries adopted Agenda 2030 for Sustainable Development and its 17 Sustainable Development Goals (SDGs). Each goal is composed of a number of targets to be achieved by 2030. The goals and the 169 targets cover a wide range of social, economic and environmental issues addressing crucial global challenges, including ending hunger and poverty, protecting life below water and on land, advancing sustainable production and consumption, and guaranteeing well-being to all with reduced inequalities. Agenda 2030 forms an overarching framework that is expected to guide government and non-state actor efforts at different scales, from global to local, until 2030. The global indicator framework to follow and periodically review the progress towards the SDG targets was adapted in 2017 (UN 2017). The main responsibility to reach the SDG targets rests with national governments, but the agenda calls for cooperation and global partnerships that bring together governments, civil society, the private sector, the United Nations (UN) system and other social actors.

The SDGs (Table I.1) and their targets form a complex, integrated system with clear sectoral emphases but also strong interlinkages among goals and targets. The agenda does not explicitly address these interlinkages, nor the synergies and trade-offs among targets. In many instances, efforts to advance one target can directly or indirectly contribute to the advancement of other targets. In other instances, progressive measures for one target can hinder the achievement of others.

Natural resources are the fundamental basis for life and human well-being. Many of the efforts to achieve the SDGs and specific targets will have direct or indirect impacts on natural resources, the services they provide and the ways they are used, along with the distribution of their benefits. Forests cover about one-third of the world's land area and are crucial for fundamental ecological processes and human well-being - from climate regulation and 


\section{Table I.1 Sustainable Development Goals}

Goal 1. End poverty in all its forms everywhere

Goal 2. End hunger, achieve food security and improved nutrition and promote sustainable agriculture

Goal 3. Ensure healthy lives and promote well-being for all at all ages

Goal 4. Ensure inclusive and equitable quality education and promote lifelong learning opportunities for all

Goal 5. Achieve gender equality and empower all women and girls

Goal 6. Ensure availability and sustainable management of water and sanitation for all

Goal 7. Ensure access to affordable, reliable, sustainable and modern energy for all

Goal 8. Promote sustained, inclusive and sustainable economic growth, full and productive employment and decent work for all

Goal 9. Build resilient infrastructure, promote inclusive and sustainable industrialization and foster innovation

Goal 10. Reduce inequality within and among countries

Goal 11. Make cities and human settlements inclusive, safe, resilient and sustainable

Goal 12. Ensure sustainable consumption and production patterns

Goal 13. Take urgent action to combat climate change and its impacts*

Goal 14. Conserve and sustainably use the oceans, seas and marine resources for sustainable development

Goal 15. Protect, restore and promote sustainable use of terrestrial ecosystems, sustainably manage forests, combat desertification, and halt and reverse land degradation and halt biodiversity loss

Goal 16. Promote peaceful and inclusive societies for sustainable development, provide access to justice for all and build effective, accountable and inclusive institutions at all levels

Goal 17. Strengthen the means of implementation and revitalize the Global Partnership for Sustainable Development

* Acknowledging that the United Nations Framework Convention on Climate Change is the primary international, intergovernmental forum for negotiating the global response to climate change.

Source: UN 2015 
pollination services to provision of timber and non-timber forest products. They also provide habitat for a vast array of plants and animals. The future of the world's forests is thus critical for sustainable development at all scales, from global to local.

Yet, forests are explicitly mentioned in only two SDGs. SDG 15 (Life on Land) focuses on the protection, restoration and sustainable use of terrestrial ecosystems and halting the loss of biodiversity. SDG 6 (Clean Water and Sanitation) calls for the protection and restoration of forests in one of its targets: Target 6.6 aims at protecting and restoring water-related ecosystems, including forests. Due to the interrelated nature of the SDGs and targets, the implementation of the SDG agenda will inevitably affect forests and forest resources, thus impacting the possibilities to achieve these forest-specific targets. This will further affect the capacity and potential of forests to provide important ecosystem services (e.g. climate regulation, soil protection and formation, biodiversity protection, water regulation and supply, and an environment for recreation) and consequently to contribute to achieving the SDGs and supporting human well-being and sustainable development in the future.

This book presents a comprehensive interdisciplinary assessment of potential and anticipated impacts of efforts towards attaining the different SDGs on forests and forest-related livelihoods. It identifies possible synergies and tradeoffs associated with efforts to achieve the SDGs and the goods and services provided by forests. The assessment places special attention on interactions among the goals and their impacts on forests, forest use and forest-related livelihoods and economies, as well as how the goals and their interactions affect policies and governance relevant to forests. We expect that this book will thus contribute to the formulation of more integrated and coherent policies for reaching the SDGs and targets - policies that would leverage beneficial synergies and minimise the inherent trade-offs among the targets. By analysing the interactions among the SDGs through a forest lens, this book provides an analysis of the SDG framework from the point of view of this crucial natural resource base on which human well-being depends.

The book addresses the following questions:

1. What are the possible and anticipated impacts of efforts to achieve the 17 SDGs and related targets on forests and forest-related livelihoods? What are the contextual conditions that determine how SDGs are implemented and prioritised, and how do these conditions and related SDG implementation pathways influence impacts on forests and related livelihoods?

2. What are the important interconnections and interlinkages among the SDGs and related trade-offs and opportunities for beneficial synergies vis-à-vis 
forests, forest ecosystem services and forest-related livelihoods in different contexts? How may the implementation of the SDGs transform existing rural well-being scenarios and forest-dependent economies?

Here, we introduce the SDGs and the processes that led to their adoption. We also summarise the importance of forests for human well-being and the crucial role and contributions of forests towards reaching the SDGs.

\section{The Road to SDGs}

The challenge of maintaining environmental sustainability in the context of economic growth and material well-being entered global discussions in the UN Conference on the Human Environment in Stockholm in 1972. Several years later, the report of the Brundtland Commission, Our Common Future, placed the concept of sustainable development into the global environmental and development agenda. It defined sustainable development as 'development that meets the needs of the present without compromising the ability of future generations to meet their own needs' (UN 1987).

Since that time, sustainable development has been the overarching theme and guiding principle of global development. It was the main concept for the UN Conference on Environment and Development held in Rio de Janeiro in 1992: the summit adopted Agenda 21 - a programme of action for sustainable development worldwide. Building on the declaration from the Stockholm conference, it presented the first international plan of action for global sustainable development into the twenty-first century (UN 1994).

The 2002 World Summit on Sustainable Development in Johannesburg, South Africa, reaffirmed this commitment and included a reference to the three pillars of sustainable development by assuming 'a collective responsibility to advance and strengthen the interdependent and mutually reinforcing pillars of sustainable development - economic development, social development and environmental protection - at the local, national, regional and global levels' (UN 2002: 1).

In 2000, the UN Millennium Summit adopted the Millennium Declaration with eight time-bound targets, the Millennium Development Goals (MDGs), with a deadline of 2015. It committed all countries to reduce extreme poverty and set a road map towards the implementation of the MDGs, which focused on eradicating extreme poverty and hunger; achieving universal primary education; promoting gender equality and empowering women; reducing child mortality; improving maternal health; combatting HIV/AIDS, malaria and other diseases; ensuring environmental sustainability; and developing a global partnership for development (UN 2000). 
The MDGs became widely accepted goals, but were mostly relevant for developing countries. While remarkable progress has been made towards these goals, especially in eradicating poverty and improving access to primary education, progress has been uneven within and across countries (UN 2012). The MDG framework's format - based on a limited number of concrete end goals and numerical targets - has been acknowledged as one of its main strengths (UN 2012). However, this approach has also been criticised for addressing complex development challenges with only eight concrete goals and reducing the development agenda to meeting basic material needs. The resulting narrow focus on selected indicators has accordingly been criticised for ignoring issues that are not captured with specific, quantifiable indicators, thus potentially leading to shifting priorities when implementing the MDGs (Fukuda-Parr 2017).

While the SDGs build on the MDGs, there are significant differences between them and the processes leading to their adoption. The process leading to the acceptance of the MDGs was criticised for being top-down, led by technocrats with limited consultations with other sources of knowledge and expertise. The process leading to the adoption of the SDGs was based on considerably broader participation. The SDGs were negotiated mainly through the Open Working Group of the UN General Assembly, whose work paralleled the work of the High-Level Panel on the Post-2015 Development Agenda set up by the UN Secretary General. The process included an extensive global consultation and negotiation involving the interests of specific social groups such as women, Indigenous peoples, farmers and non-governmental organisations (Dodds et al. 2017, Fukuda-Parr 2016, Stevens and Kanie 2016).

The SDGs broadened the focus from that of the MDGs towards a wider development policy agenda addressing many aspects of economic, social and environmental sustainability. While the MDGs were mainly relevant for developing countries, the SDGs apply to all countries. They also address issues that were not included in the MDGs and ones that the MDGs were criticised for only partially including, such as inequality, gender, political and human rights, economic development and climate change.

Agenda 2030 is a universal plan of action that aims at guiding development efforts and national development policies until 2030. It recognises that the SDGs are 'integrated and indivisible and balance the three dimensions of sustainable development: the economic, social and environmental' (UN 2015: 1). Universal development and ending poverty in the spirit of 'no one will be left behind' are the central principles of Agenda 2030. 'Eradicating poverty in all its forms and dimensions, including extreme poverty' is considered the 'greatest global challenge and an indispensable requirement for sustainable development' (UN 2015: 1). 


\section{SDGs as a Complex, Integrated System}

While the SDGs are stated to form a complex, integrated system of goals and interrelated targets that cut across traditional administrative sectors, many of the goals have an overall sectoral focus. Furthermore, the references to sectors other than the ones specifically addressed in a specific goal are not systematically considered (Boas et al. 2016). There is great variation in the nature and scope of the SDGs, and the related targets have different functions. Some targets are ends in themselves, while others are means towards reaching other targets by supporting the development of an enabling environment or providing resources that support the achievement of other targets (Elder et al. 2016, Holden et al. 2017). The relationship among the more intermediate targets can be synergistic, and a lack of progress in one may often hinder progress within another. In other instances, however, efforts towards achieving a specific target can undermine progress towards another one (Elder et al. 2016). While synergies among the targets can increase the effectiveness of implementation, incompatible targets lead to trade-offs. In addition, the interactions among the SDGs are non-linear. Deficient performance in one crucial goal or target can potentially undermine progress in the overall agenda. Similarly, the implementation of one target at the expense of a non-compatible one can reinforce the trade-offs.

The interlinkages and interactions among the SDGs and related targets are receiving increasing attention. Le Blanc (2015) conducted a network analysis of the links among SDGs and targets (except those related to implementation) based on their wording. The results show that the SDGs are unequally connected. Some goals are connected through multiple targets, while others have weak connections to other goals. Sustainable consumption and production (SDG 12), reducing inequality (SDG 10), eliminating poverty (SDG 1) and promoting economic growth and employment (SDG 8) are directly or indirectly linked to at least ten other goals. Life on land (SDG 15) is linked to six other goals. The results of the network analysis were compared to previous studies that had used a nexus approach to analyse the interconnections among climate, land, energy and water targets. This showed that most of the relevant interactions identified in nexus studies are not explicitly captured in the wording of the SDGs and targets.

SDG interactions have also been analysed through classifying and clustering the goals and their interactions. Waage et al. (2015) have proposed a framework whereby the SDGs are grouped into three domains and represented by three nested circles: well-being (comprising SDGs 1, 3, 4, 5, 10, 16) in the inner circle, infrastructure (comprising SDGs 2, 6, 7, 8, 9, 11, 12) in the middle circle and environment (comprising SDGs 13, 14, 15) in the 
outer circle. The potential interactions among SDGs are closely related to their position in the framework. The authors argue that there is potential for synergies among the goals in the inner level as they focus on different aspects of human well-being. Similarly, the outer-level environmental goals are interrelated and potentially synergistic. The infrastructure goals in the middle contribute to the achievement of the well-being goals, but compete for limited environmental resources such as land for agriculture, forestry or energy. The trade-offs between the inner- and outer-level goals need to be addressed within the infrastructure goals, which requires effective governance of these goals (Waage et al. 2015).

Different approaches have been proposed to address the interlinkages among the goals and targets. In this connection the nexus approach has gained renewed attention. For instance, the UN Prototype Global Sustainable Development Report (UN 2014: 21) advocates for the climate-land-energywater-development nexus as a 'pragmatic approach to integrated assessment for selected clusters of strongly interlinked issues'. In general, the nexus approach aims at increasing policy coherence across sectors. The waterenergy-food nexus has received special attention as a research agenda and development paradigm (Biggs et al. 2015, Bizikova et al. 2013, FAO 2014, Hoff 2011, Leck et al. 2015, Weitz et al. 2016). The downside of the nexus approach is that it specifically focuses on the interactions among a chosen, limited number of SDGs and targets, and thus fails to acknowledge possible important linkages to other SDGs that could be crucial for the specific SDGs under study.

As an attempt to develop a more comprehensive approach, Nilsson et al. (2016) present a framework consisting of a typology of interactions, where the interactions and relationships among SDG targets are assigned scores ranging from +3 (indivisible), +2 (reinforcing), +1 (enabling) and 0 (neutral) to -1 (constraining), -2 (counteracting) and -3 (cancelling). This framework is suggested as an approach to systematically assess the target-level interactions. It recognises that the scoring is context specific and is affected by timescale, governance arrangements, technology and geography.

As these analyses demonstrate, the SDGs and related targets form a complex, interconnected set of different kinds of goals. However, these interconnections are neither systematically recognised nor addressed in the SDG agenda: 'A tendency to ignore interlinkages among sectors and across national borders has meant that success in one area or location has all too often come at the expense of increasing problems elsewhere' (UN 2014: 21). Understanding the interactions among the targets is thus fundamental for making comprehensive progress towards the targets and ensuring that progress towards a specific target is not impeding the achievement of other targets (Griggs et al. 2017). 


\section{Forests and SDGs}

Human welfare is ultimately based on global natural resources and biodiversity; the sustainable use of these resources within environmental limits is the foundation for sustainable development (Holden et al. 2017). Forests cover about one-third of global land area, totalling nearly 4000 million ha (FAO 2016a). However, ecological, social and economic conditions vary greatly in different parts of the world, among countries and even within countries, leading to great variations in forest-human interactions, the importance and potential contributions of forests for achieving the SDGs, and the potential and likely impacts of policies and measures for progressing towards the SDGs.

\section{Brief Overview of the World's Forests}

The global forest area is made up of 3695 million ha of natural forest and 291 million ha of planted forest. ${ }^{1}$ Natural forest area continues to decline and planted forest area to increase. From 2010 to 2015, the natural forest area worldwide decreased by 6.5 million ha per year, while the reported planted area increased by 3.3 million ha per year. Most planted forests are located in Asia, with 129 million ha, followed by Europe, with 83 million ha (FAO 2016a).

Most of the world's forests are located in tropical countries (44 per cent), followed by temperate ( 26 per cent), boreal ( 22 per cent) and subtropical countries (8 per cent). Forest loss has also been concentrated in tropical countries, particularly in South America and Africa: from 2010 to 2015, tropical forest area declined by 5.5 million ha per year. In general, forest area has declined in Central America, South America, South and Southeast Asia and in Africa, while increasing in Europe, North America, the Caribbean, East Asia and Western-Central Asia (Keenan et al. 2015).

The pressures on forests are related to population growth through the increasing demand for forest-based products and services and through increasing competition for the use of land currently forested. The world's population has increased concurrently with global forest loss, leading to declining per capita forest area. While on average it declined from 0.8 ha to 0.6 ha per capita from 1990 to 2015, during this period the forest area per capita in the tropics nearly halved and declined by more than 35 per cent in the subtropics (FAO 2016a, Keenan et al. 2015).

${ }^{1}$ FAO (2012) definition of forest: Land spanning more than 0.5 hectares with trees higher than 5 metres and a canopy cover of more than 10 per cent, or trees able to reach these thresholds in situ. 
Forest ownership and management rights are an essential part of forest governance; they are important in shaping the ways forests are used and managed and for the distribution of related costs and benefits. Most of the world's forests (76 per cent) are publicly owned, and about 20 per cent are privately owned; for the rest, information is not available (FAO 2016a). Public ownership is highest in Western and Central Africa (99 per cent), Western and Central Asia (98 per cent) and South and Southeast Asia (90 per cent).

The share of privately owned forests is highest in East Asia and Oceania (42 per cent) and North America (33 per cent) (FAO 2016a). The category of privately owned forests includes forests legally held by individuals, communities and firms. Individual, smallholder and family forest ownership is dominant in many European countries; it is increasing in countries with formerly centrally planned economies due to privatisation and restitution policies (Forest Europe 2015). Forest tenure reforms in China and Vietnam have led to forestland being allocated, leased or contracted to individuals and families, increasing the forest area under some degree of private management (Hou et al. 2017, Yasmi et al. 2017). In the United States, 58 per cent of forests are under private ownership, including private corporate ownership, which covers 19 per cent of forests.

According to the Rights and Resources Initiative data from 58 countries, covering 92 per cent of global forest area, private individuals and firms own 11 per cent and Indigenous and local communities 12 per cent of the total forest area in the analysed countries (RRI 2018). The areas owned by Indigenous and local communities totalled 447 million ha in 2017. Furthermore, Indigenous and local communities hold legally designated rights to $80.5 \mathrm{mil}-$ lion ha of the publicly owned forests, meaning that 'national law recognises Indigenous Peoples' and local communities' rights to access and withdrawal, as well as to participate in the management of forests or to exclude outsiders' (RRI 2018: 8). Taken together, most forest area either legally owned by or designated for Indigenous and local communities is located in Latin America, followed by Asia and then Africa (RRI 2018).

Governments maintain legal and administrative authority over publicly owned forest areas; a large part of this is used and managed by Indigenous and local communities on the basis of customary, community-based tenure systems without formal government recognition. This, combined with the fact that large areas of government-administered forests have been granted to companies and investors under concession and license agreements without acknowledging the existing customary rights, has led to conflicts and disputes over forestland (RRI 2018). This situation has had serious negative livelihood implications for peoples residing in and around forests. 


\section{Forests' Contributions to SDGs}

Forests provide ecosystem services that are crucial for human welfare. The contributions of forests to achieving the SDGs were explored before the SDGs were formally adopted and have since been further analysed and discussed (Brack 2014, FAO 2016b, 2018; Grazer and Keeton 2017, Sunderland et al. 2013, Vira et al. 2015). Forests can be directly or indirectly linked to each of the SDGs. Forests provide plant- and animal-based products that are important as foods and medicines, contributing directly to ending hunger (SDG 2) and ensuring health and well-being (SDG 3). Forestry employment can contribute to providing decent work (SDG 8) and forest-based incomes can contribute to ending poverty (SDG 1), and these incomes can be used to buy food, which further contributes to food security (SDG 2). Forests also provide clean water and influence hydrological cycles and downstream water supply, contributing to water and sanitation (SDG 6). Forest biomass can contribute to reducing global dependence on fossil fuels for energy (SDG 7), and forests can contribute to responsible consumption and production (SDG 12) by providing renewable materials to substitute non-renewable ones. Forests can also support industrial development and innovation (SDG 9). Some forest communities are among the most equitable globally, relating to gender (SDG 5) and equality (SDG 10), while participatory forest management approaches contribute to inclusive societies and building inclusive institutions (SDG 16). Forests are crucial for carbon storage and for regulating climate (SDG 13). Forests also provide supporting services, such as nutrient cycling and crop pollination, that are fundamental for sustainable agricultural production. Furthermore, mangroves (SDG 14) provide coastal protection benefits, strengthening coastal community resilience to climate-related hazards. Forest-related cultural ecosystem services include recreational, spiritual, religious and other non-material benefits. These benefits are important for rural and urban populations and contribute to learning and physical and mental well-being (SDG 4 and SDG 3) and more resilient and sustainable cities (SDG 11). Furthermore, most of the world's terrestrial biodiversity is found in forests (SDG 15).

Forest ecosystem services contribute to human welfare at different scales. At a global scale, all people benefit from the climate change mitigation and crop pollination services of forests. A large share of the global population also benefits from forest-based products such as wooden furniture or timber for housing. In addition, it is estimated that 350 million rural inhabitants are highly dependent on forests for food security, livelihoods and energy, while an estimated 60 million Indigenous peoples are totally dependent on forests for their subsistence (World Bank 2008). 


\section{Impacts of SDGs on Forests and Livelihoods}

As already noted, despite the profound importance of forests for human wellbeing and their important role in reaching the SDGs, forests are only mentioned in two: in single targets under SDGs 6 (Clean Water and Sanitation) and 15 (Life on Land). Due to the interrelated nature of the SDGs and targets previously discussed, the implementation of the SDG agenda will inevitably influence the possibilities to achieve these forest-specific targets. In addition, SDG implementation will likely affect the capacity and potential of forests to provide the important ecosystem services described and consequently sustain forests' contributions to achieving the SDGs.

The implementation of the SDGs is principally in the hands of national governments: 'Targets are defined as aspirational and global, with each Government setting its own national targets guided by the global level of ambition but taking into account national circumstances. Each Government will also decide how these aspirational and global targets should be incorporated into national planning processes, policies and strategies' (UN 2015: 13). From the viewpoint of international law, the SDGs are considered as norms at the 'softest end of the soft law-hard law continuum' (Persson et al. 2016: 60). SDG 17 focuses specifically on the means of implementation, concentrating on finance, technology, capacity-building, trade and systemic issues, including policy and institutional coherence, multistakeholder partnerships and data, monitoring and accountability. In addition, specific targets under each SDG relate to the implementation of the given SDG. Yet many targets are rather vague, aspirational-outcome targets that do not specify the ways or conduct by which they should be achieved: different pathways can be taken (Persson et al. 2016). Moreover, the implementation targets do not address the interdependencies and interlinkages among the goals and targets (Stafford-Smith et al. 2017). Beyond the key role national governments play in Agenda 2030, it is important to recognise the emerging importance of regional and local governments, communities and private-sector entities in SDG implementation.

The implementation of the SDGs varies according to economic prosperity, political stability, social cohesion and national circumstances, such as geographic features, natural resource base, level of technological development, and policy, institutional and social frameworks. National circumstances and development priorities will influence how the SDGs are prioritised and how they are included in national policies and strategies. In this connection, the extent and condition of forest resources and the role of forests in industrial development and for livelihoods, as well as social and cultural perspectives and voices pertaining to forest use and conservation, are important factors 
in shaping the policies and strategies that relate to forests and the relative importance given to forests in relation to other land uses.

Understanding the potential impacts of SDGs on forests, forest-related livelihoods and forest-based options to generate progress towards achieving the SDGs, as well as the related trade-offs and synergies, is crucial to the efforts undertaken to reach these goals. It is especially important for reducing potential negative impacts and to leverage opportunities to create synergies that will ultimately determine whether comprehensive progress towards the SDGs will be accomplished.

Little attention, however, has yet focused on possible and likely impacts that efforts undertaken by different sectors to advance towards the 17 SDGs will have on forests, forest ecosystem services, forest-related livelihoods and human well-being, or on how these impacts, in turn, will contribute to or undermine the contributions of forests in achieving the SDGs. Efforts to achieve the SDGs may result in an emphasis on forest management and production or on forest protection, or a combination of both. Where the emphasis lies will affect the ecosystem services provided by forests and the associated benefits accruing to different segments of society. In this light, efforts to achieve some of the SDGs will likely drive additional land-use change and deforestation. Developments in sectors such as agriculture, transport, mining and energy may have crucial implications for forest-related development. Policies and actions to improve governance and build effective institutions for natural resource management may affect the conditions shaping forest resource use, benefit-sharing and sustainable production, while also affecting gender concerns and wider issues of social equity and equality.

Impacts of SDG implementation can vary according to geographical scale. National policies favouring more gender-equitable land tenure, for instance, can wind up being ignored at the local level. Progress on a particular SDG in one location can lead to harmful impacts in other locations. For example, a study on seven developing countries that have experienced forest transition a shift from net deforestation to net increase in forest cover - found that in most cases reforestation was accompanied with deforestation in other countries through trade in timber and agricultural products (Meyfroidt et al. 2010).

The impacts can also vary according to the time horizon. Intensifying the use of forest products (e.g. collection of non-timber forest products) can support livelihoods and increase incomes in the short term, but in the long term may lead to depletion of the resource base and reduced availability of these products, resulting in declining incomes.

Assessing the impacts of the SDGs and related policies on forests and people is not a trivial undertaking. It requires a thorough look into the SDGs and the inherent trade-offs and synergies among them, the contextual factors 
that shape how the SDGs are prioritised and implemented, and the consequent impacts on forests and people.

Chapters 1 to 17 focus on the potential impacts of the implementation of the SDGs on forests and forest-related livelihoods and economies, taking into account the considerations discussed. Each chapter is dedicated to the analysis of one of the 17 SDGs. The analyses focus especially on people who live in or near forests and who depend on forests for their material, social, cultural and emotional well-being. In the following chapters these impacts are generally referred to as impacts on 'forests and people'. Based on existing evidence, these chapters identify the most important contextual conditions that guide or determine how a specific SDG is prioritised or pursued and discuss the possible impacts of its implementation on forests and the goods and services forests provide in different contexts. They also consider the linkages among the SDGs, identifying important opportunities for synergies and drawing attention to possible or unavoidable trade-offs.

Chapter 18 synthesises the findings from Chapters 1 to 17 . Chapter 19 concludes with broad conclusions on a few key lessons learnt, with a view to providing guidance for the future co-evolution of people and forests in a changing world.

\section{of References}

Biggs, E. M., Bruce, E., Boruff, B. et al. 2015. Sustainable development and the water-energyfood nexus: A perspective on livelihoods. Environmental Science \& Policy 54:389-97.

Bizikova, L., Roy, D., Swanson, D., Venema, H. D. and McCandless, M. 2013. The WaterEnergy-Food Security Nexus: Towards a practical planning and decision-support framework for landscape investment and risk management. Winnipeg: International Institute for Sustainable Development Report.

Boas, I., Biermann, F. and Kanie, N. 2016. Cross-sectoral strategies in global sustainability governance: towards a nexus approach. International Environmental Agreements 16:449-464. doi:10.1007/s10784-016-9321-1

Brack, D. 2014. Sustainable Development Goals and Forests. A summary of UN Open Working Group debates and country reflections. UK: IIED.

Dodds, F., Donoghue, D. and Roesch, J. L. 2017. Negotiating the Sustainable Development Goals. A transformational agenda for an insecure world. London: Routledge.

Elder, M., Bengtsson, M. and Akenji, L. 2016. An optimistic analysis of the means of implementation for Sustainable Development Goals: Thinking about goals as means. Sustainability 8:962. doi:10.3390/su8090962.

FAO 2012. FRA 2015 terms and definitions. Forest Resources Assessment Working Paper 180. Rome: FAO. 
FAO 2014. The water-energy-food nexus: A new approach in support of food security and sustainable agriculture. Rome: FAO.

FAO 2016a. Global forest resources assessment 2015. How are the world's forests changing? 2nd ed. Rome: FAO.

FAO 2016b. Forest-related indicators: Monitoring and reporting progress related to the achievement of the Sustainable Development Goals. Committee on Forestry, 23rd session, Rome, 18-22 July. COFO/2016/5.2.

FAO 2018. State of the world's forests 2018: Forest pathways to sustainable development. Rome: FAO. Forest Europe 2015. State of Europe's forests 2015. Madrid: Ministerial Conference on the Protection of Forests in Europe.

Fukuda-Parr, S. 2016. From the Millennium Development Goals to the Sustainable Development Goals: Shifts in purpose, concept, and politics of global goal setting for development. Gender \& Development 24(1):43-52. doi:10.1080/13552074.2016.1145895.

Fukuda-Parr, S. 2017. Millennium Development Goals: Ideas, interests and influence. New York: Routledge.

Gratzer, G. and Keeton, W. S. 2017. Mountain forests and sustainable development. The potential for achieving the United Nations' 2030 Agenda. Mountain Research and Development 37(3):246-53.

Griggs, D. J., Nilsson, M., Stevance, A. and McCollum D. (eds.) 2017. A Guide to SDG interactions: From science to implementation. Paris: International Council for Science (ICSU).

Hoff, H. 2011. Understanding the nexus. Background Paper for the Bonn 2011 Conference: The Water, Energy and Food Security Nexus. Stockholm: Stockholm Environment Institute.

Holden, E., Linnerud, K. and Banister, D. 2017. The imperatives of sustainable development. Sustainable Development 25:213-26.

Hou, J., Yin, R. and Wu, W. 2017. Intensifying forest management in China: What does it mean, why, and how? Forest Policy and Economics 98:82-9.

Keenan, R. J., Reams, G. A., Achard, F. et al. 2015. Dynamics of global forest area: Results from the FAO Global Forest Resources Assessment 2015. Forest Ecology and Management 352:9-20.

Le Blanc, D. 2015. Towards integration at last? The Sustainable Development Goals as a network of targets. Sustainable Development 23(3):176-87.

Leck, H., Conway, D., Bradshaw, M. and Rees, J. 2015. Tracing the water-energy-food nexus: Description, theory and practice. Geography Compass 9(8):445-60.

Meyfroidt, P., Rudel, T. K. and Lambin, E. F. 2010. Forest transitions, trade, and the global displacement of land use. Proceedings of the National Academy of Sciences 107(49):20917-22.

Nilsson, M., Griggs, D., Visbeck, M., Ringler, C. and McCollum, D. 2016. Introduction. A framework for understanding Sustainable Development Goal interactions. In Griggs, D. J., Nilsson, M., Stevance, A. and McCollum D. (eds.), A guide to SDG interactions: From science to implementation. Paris: International Council for Science, pp. 18-30.

Persson, A., Weitz, N. and Nilsson, M. 2016. Follow-up and review of the Sustainable Development Goals: Alignment vs. internalisation. RECIEL 25(1):59-68. 
RRI (Rights and Resources Initiative) 2018. At a crossroads: Consequential trends in recognition of community-based forest tenure from 2002-2017. Washington, DC: RRI.

Siry, J. P., Cubbage, F. W., Potter, K. M. and McGinley, K. 2018. Current perspectives on sustainable forest management: North America. Current Forestry Reports 4(3):138-49.

Stafford-Smith, M., Griggs, M., Gaffney, O. et al. 2017. Integration: The key to implementing the Sustainable Development Goals. Sustainability Science 12:911-19. doi:10.1007/s11625016-0383-3.

Stevens, C. and Kanie, N. 2016. The transformative potential of the Sustainable Development Goals (SDGs). International Environmental Agreements: Politics, Law and Economics 16(3):393-6.

Sunderland, T., Powell, B., Ickowitz, A. et al. 2013. Food security and nutrition. The role of forests. Discussion Paper. Bogor, Indonesia: CIFOR.

UN 1987. Report of the World Commission on Environment and Development: Our common future. New York: United Nations.

UN 1994. Agenda 21. Programme of Action for Sustainable Development. Rio Declaration on Environment and Development. Statement of Forest principles. The final text of agreements negotiated by Governments of the United Nations Conference on Environment and Development (UNCED), 3-14 June 1992, Rio de Janeiro, Brazil.

UN 2000. Resolution adopted by the General Assembly. A/RES/55/2. 55/2 United Nations Millennium Declaration. 18 September 2000.

UN 2002. Report of the World Summit on Sustainable Development. Johannesburg, South Africa, 26 August-4 September 2002 A/CONF.199/20.

UN 2012. Realizing the future we want for all. Report to the Secretary-General. UN, New York 2012. Available at: www.un.org/en/development/desa/policy/untaskteam_undf/untt_report .pdf (Accessed 20 July 2018).

UN 2014. Prototype global sustainable development report. New York: United Nations Department of Economic and Social Affairs, Division for Sustainable Development, July 2014. Available at: http://sustainabledevelopment.un.org/globalsdreport/ (Accessed 20 July 2018).

UN 2015. Resolution adopted by the General Assembly on 25 September 2015. Transforming our world: the 2030 Agenda for Sustainable Development. UN A/RES/70/1. Available at: www .un.org/ga/search/view_doc.asp?symbol=A/RES/70/1\&Lang=E (Accessed 20 July 2018).

UN 2017. Resolution adopted by the General Assembly on 6 July 2012. 71/313. Work of the Statistical Commission pertaining to the 2030 Agenda for Sustainable Development. A/RES/71/313. Available at: https://undocs.org/A/RES/71/313 (Accessed 22 February 2019).

Vira, B., Wildburger, C. and Mansourian, S. (eds.) 2015. Forests, trees and landscapes for food security and nutrition: A global assessment report. IUFRO World Series no. 33. Vienna: International Union of Forest Research Organizations.

Waage, J., Yap, C., Bell, S. et al. 2015. Governing Sustainable Development Goals: Interactions, infrastructures, and institutions. In Waage, J. and Yap, C. (eds.) Thinking beyond sectors for sustainable development. London: Ubiquity Press, pp. 79-88. doi:http://dx.doi.org/10.5334/ bao.i. 
Weitz, N., Strambo, C., Kemp-Benedict, E. and Nilsson, M. 2016. Closing the governance gaps in the water-energy-food nexus: Insights from integrative governance. Global Environmental Change 45:165-73.

World Bank 2008. Forests sourcebook: Practical guidance for sustaining forests in development cooperation. Washington, DC: World Bank. Available at: http://documents.worldbank.org/ curated/en/356731468155739082/Forests-sourcebook-practical-guidance-for-sustainingforests-in-development-cooperation (Accessed 14 February 2019).

Yasmi, Y., Ram Dahal, G. and De Bruyn, T. 2017. Forest tenure in Cambodia, Nepal and Viet Nam. Regional Office for Asia and the Pacific, Food and Agriculture Organization of the United Nations, Bangkok: FAO. 